\title{
TECHNICAL EFFICIENCY AND SCALE EFFICIENCY OF SUGARCANE PRODUCTION
}

\author{
Fahriyah, Hanani Nuhfil, Koestiono Djoko, Syafrial* \\ Department of Socio Economic Agriculture, Faculty of Agriculture, University of Brawijaya, \\ Indonesia \\ *E-mail: syafrial ub@ub.ac.id \\ ORCID: 0000-0001-9049-876X
}

\begin{abstract}
Sugar consumption in Indonesia is dominated by households and industry consumption. During 2015-2016, consumption of households was 2.9 MT and industry - 2.7 MT. On the same period, sugar production was 2.497 MT only. The gap between domestic output and demand of sugar increased gradually, and now Indonesia is becoming one of the biggest sugar net-importers. The dependence on large quantity of imported sugar has to be minimized. Scarcities of land and production resources require a strategy to increase agricultural productivity by using resources efficiently. Coelli et al (2002) revealed that the technical efficiency has an important role in productivity and agricultural growth. Therefore, efforts attempt to measure the technical efficiency of farming activities needs to be done in order to obtain an increase efficient productivity. The objective of this study is to analyze how the resource inputs were efficiently used determine scale efficiency of sugarcane farmers. Results show that the average technical efficiency and scale efficiency level are 0.917 and 0.856 respectively. Sugarcane farmers who had low TE scores (technically inefficient) were farmers who allocated their inputs (seed, fertilizer, herbicide and labor) excessively. This study also provides evidence that only $13 \%$ of sugarcane farmers in Kediri District who operate on optimal scale (Constant Return to Scale).
\end{abstract}

\section{KEY WORDS}

Sugarcane, technical efficiency, scale efficiency, farmers, production.

Sugar has been a major agro based industry in Indonesia since the 19th century and has made significant contributions in the rural economy of Indonesia. Whereas the sugar industry has taken roots in a number of new regions like Africa and has grown rapidly in countries like India, Brazil and Thailand but has remained stagnant in Indonesia. Sugarcane is the most important commodity; in terms of sugarcane is one of main input in sugar industry. Toharisman and Triantarti (2016) reported that during 2004-2015, the growth of area planted to sugarcane was about $3.5 \%$. Planted area of sugarcane in 2015 , the planted area was 466.06 million ha.

The demand of sugar in Indonesia is not only dominated by household consumption but also industry, especially food and beverage industry. During 2015-2016, sugar industry consumption was 5.6 MT. In other hand, on the same periode, sugar production was only 2.47 MT. Growth of productivity was relative stagnan (4.09\%). Fulfillment of demand sugar in domestic market has led government to import sugar continuously. Sugar consumption per capita $22 \mathrm{~kg} /$ capita/year.

Scarcity of sugarcane production resources and land competition require a strategy to increase productivity by using resources efficiently. Coelli, et al (2002) revealed that the technical efficiency has an important role in productivity and agricultural growth. Meanwhile Fried et al. (2008) showed that one way to reduce production costs to increase agricultural production by improving technical efficiency. Therefore, efforts attempt to measure the technical efficiency of farming activities needs to be done in order to obtain an increase efficient productivity.

The measurements of efficiency and the estimation of production frontiers were researched extensively after Farrell's (1957) seminal work. The efficiency of a firm has two components: technical (or physical) efficiency and allocative (or price) efficiency. Technical 
efficiency (TE) measures the ability of a farm to produce maximal potential output from a given input. Allocative efficiency (AE) measures the ability of a farm to utilize the costminimizing input ratios or revenue-maximizing output ratios. One needs to be technically efficient before one can be allocatively efficient and attainment of both is required for economic efficiency (Coelli, 1995).

Estimation of a production frontier differs depending on the assumptions made about the outer bound of the frontier, which may be deterministic or stochastic, while the technique for estimation may be parametric, or non-parametric. Currently, the stochastic frontier and the deterministic non-parametric methods are the primary approaches and these involve econometric methods and mathematical programming respectively (Coelli, et.al.,1995). The choice between these techniques depends on the underlying reasons for estimating productive efficiency. The advantages of deterministic, non-parametric approach using Data Envelopment Analysis (DEA) are it can identify the sources and the level of inefficiency for each farm unit.

This paper attempts to estimate technical efficiency and scale efficiency of sugarcane production in dry land. By conducting technical efficiency analysis it is possible to illustrate whether harvesting more sugarcane is still viable by improving present input use efficiency. Moreover, by conducting scale efficiency (SE) analysis it is possible to draw a clear picture in terms of farm size and technical efficiency (TE) relationship in sugarcane production. In other words, technical efficiency refers to the utilization of production factors in the most efficient way, whereas SE provides information about how optimal sugarcane growing land size should be given the other input resources.

\section{METHODS OF RESEARCH}

Data and Sample. The data for this study was obtained from a survey of sugarcane farmers in Kediri District, the largest sugarcane producing region in East Java Province. Sugarcane farmer were then sampled using multistage random sampling. Data was collected using a structured questionnaire, on farmers' output of sugarcane, inputs used in the production process (land, labor, fertilizer, pesticide and seeds) and the socio-economic characteristics like farmer's age, level of education, family members, and land size.

The number of sample taken for this research based on the formula promoted by Slovin as follow:

$$
\mathrm{n}=\frac{\mathrm{Np}}{1+\mathrm{Ne}^{2}}
$$

Where: $\mathrm{Np}=$ number of population; $\mathrm{N}=$ sample size; $\mathrm{e}^{2}=$ margin of error.

Having 1090 of sugarcane farmers in the village, margin error accepted is 9.6 percent; the result of sample size is around 98.7 respondents. Therefore, the data collected are coming from 100 respondents.

Data Analysis. This research is observing the performance of farmers regarding allocation of their resources to produce optimal output. DEA approach is used to estimate production frontier. The production frontier represents maximum output attainable from each input level and it reflects the current state of technology in the farming (Coelli,1995). This method measures the relative efficiency of the Decision Making Units-DMUs (maize farms in this study) by estimating an empirical production frontier from the actual input and output data from each farm. The efficiency score of a farm is then measured by the distance between the actual observation and the frontier obtained from all the farms under evaluation. This frontier is constructed by the solution of a sequence of linear programming (LP) problems - one for each farm in the sample.

DEA can be either output or input-orientated. The output-orientated DEA method seeks the maximum proportional increase in output production with input levels held fixed. The input-orientated DEA method defines the frontier by seeking the maximum possible proportional reduction in input usage, with output levels held constant. The two measures 
provide the same technical efficiency scores when constant returns to scale (CRS) technology applies, but are unequal when variable returns to scale (VRS) is assumed (Färe et. al., 1994 ). This study uses a VRS technology (BCR model) and selected an input orientation because the concern is to minmize input usage to produce an output level, rather than the converse. An ouput oriented VRS model was developed by Banker, Charnes and Cooper (1984), is defined as:

$$
\text { Maximize }_{\theta \lambda} \theta
$$

Subject to:

$$
\begin{aligned}
& -\theta \mathrm{yi}+Y \lambda \geq 0 \\
& X i-X \lambda \geq 0 \\
& N 1^{\prime} \lambda=1 \\
& \lambda \geq 0
\end{aligned}
$$

Where $\theta$ is a scalar shows the technical efficiency (TE) score of a sample of farmers. Value of score TE range between 0 with 1 . Yi is the total production of sugarcane from $i^{\text {th }}$ farmer, $x i$ is a vector $\mathrm{Nx} 1$ of the number of inputs to $\mathrm{i}^{\text {th }}$ farmer, $\mathrm{Y}$ is a vector is $1 \times \mathrm{M}$ for production, $\mathrm{N}$ is the nxm matrix of production inputs used by farmers, $\lambda$ is the vector of weighted MX1.

The measure of technical efficiency obtained in this model is also named 'pure technical efficiency' as it is free of scale effects. Therefore, the scale efficiency values for each analyzed sugarcane farm can be obtained by the ratio between the scores for technical efficiency with constant and variable returns. Calculation of SE scores is presented by formulation below:

$$
S E=\frac{T E_{C R S}}{T E_{V R S}}=\frac{\theta_{C R S}}{\theta_{V R S}}
$$

\section{RESULTS OF STUDY}

The characteristics of farmers regarding the age, level of education, family members, land size of sugarcane farming and type of land are shown in Table 1. It is about 85 percent of farmers are less than 58 years. Most of farmers are graduated from high school level (junior and senior high school), which is about 83 percent, and family members is generally in the range of 1 up to 3 persons. On average, the land size of the farmers in the research location is 5.07 hectare and the standard deviation is about 2.02 hectare. Moreover, type of land is $65 \%$ sugarcane farmers work on dry land.

Table 1 - Characteristics of Respondents

\begin{tabular}{lllrr}
\hline No & Characteristics & \multicolumn{1}{c}{ Category } & $\begin{array}{c}\text { Number of Farmers } \\
\text { (Persons) }\end{array}$ & $\begin{array}{c}\text { Percentage } \\
(\%)\end{array}$ \\
\hline 1 & Age & $229-38$ & 8 & 8.00 \\
& & $339-48$ & 30 & 30.00 \\
& & $449-58$ & 47 & 47.00 \\
& & $559-68$ & 15 & 15.00 \\
\hline 2 & Education & No Education & 3 & 3.00 \\
& & Elementary School & 14 & 14.00 \\
& & Junior High School & 27 & 27.00 \\
& & Senior High School & 56 & 56.00 \\
\hline 3 & Family members & $1-3$ & 61 & 61.00 \\
& & $4-6$ & 38 & 38.00 \\
& & $7-9$ & 1 & 1.00 \\
\hline 4 & Land Size (Ha) & $\leq 2.00$ & 8 & 8.00 \\
& & $2.00<-\leq 4.00$ & 33 & 33.00 \\
& & $4.00<-\leq 6.00$ & 37 & 37.00 \\
& & $6.00<-\leq 8.00$ & 16 & 16.00 \\
& & $>8$ & 6 & 6.00 \\
\hline 5 & Type of Land & Wet & 35 & 35.00 \\
& & Dry & 65 & 65.00 \\
\hline
\end{tabular}

Source: Survey data, 2017. 
DEA analysis is applied in order to measure score of technical efficiency for every sugarcane farmer in the research location. The results of DEA analysis show almost $64 \%$ of samples are inefficient (Table 2). Mean pure technical efficiency (TE VRS) score is 0.9105 . It implies on average, the respondents are able to obtain around $91.7 \%$ of potential output from a given mix of inputs. This condition also implies that around $8 \%$ of sugarcane production, on average, is foregone due to technical inefficiency. In other words, the shortfall of the observed output from the frontier output primarily reflects the inefficient use of the factors that are within the control of the farmers. The technical efficiency levels of the inefficient farms range from 0.704 to 0.995 so there is a potential to increase farm output from between 0.5 and $29.6 \%$ from the existing level of inputs.

Table 2 - Distribution of Technical Efficiency Score

\begin{tabular}{lccc}
\hline \multicolumn{1}{c}{ No } & Efficiency Score & Number of Farmers (Person) & Percentage (\%) \\
\hline 1 & 1.0000 & 36 & 36.00 \\
2 & $0.927-0.999$ & 19 & 19.00 \\
3 & $0.853-0.926$ & 20 & 20.00 \\
4 & $0.779-0.852$ & 14 & 14.00 \\
5 & $0.704-0.778$ & 11 & 11.00 \\
\hline Total & & 100 & 100.00 \\
\hline Maximum & 1.000 & & \\
\hline Minimum & 0.704 & & \\
\hline Mean & 0.917 & & \\
\hline Std. Deviation & 0.0896 & &
\end{tabular}

Source: Survey Data, 2017.

To demonstrate how DEA is used to evaluate the input decisions of technically inefficient farms, and to estimate potential yield gains from reallocating inputs, consider farm 8 with an efficiency score of 0.857 . The production practices and its referents (farms 1,26 , 28 and 52) that are efficient are presented in Table 3. The use of all inputs (i.e, land, seed, fertilizer, herbicide and labor) by farm 8 is 'excessive.' This comparison would suggest strategies for farm 8 to rationalize the use of its inputs. Values of slack provide a composite farm which would produce the equivalent level of output, but by using lower levels of inputs. Average slack variables also show that input use of farms are excessive.

Table 3 - Input Use Level of Farm 8 and Its Refferent Farms

\begin{tabular}{lccc}
\hline \multicolumn{1}{c}{ Variables } & Input Use of Farm 8 & Slack & Input Use of Refferent Farms (1, 26, 28 and 52) \\
\hline Output & 5600 & 0 & 5600 \\
Land (ha) & 5.5 & -0.787 & 4.713 \\
Seed (kg) & 8000 & -1144.82 & 6855,18 \\
Fertilizer (kw) & 86 & -12.307 & 73.693 \\
Pesticide (Lt) & 30 & -4.293 & 17.406 \\
Labor (Person/day) & 116.63 & $-16,69$ & 60.313 \\
\hline
\end{tabular}

Source: Survey Data, 2017.

In order to substantiate the nature of scale inefficiencies, the analysis further disaggregated into those farms that exhibit IRS and DRS. Information as to whether a farm is operating at increasing or decreasing returns to scale can prove useful in indicating a potential redistribution of farm resources i.e. increase the input size if IRS and decrease the input size if DRS were prevailing to maximize average productivity. Turning to scale efficiency score of sugarcane farmers, more farms are operate below the optimal scale than farms above the optimal scale (Figure 1). Of the 100 sample sugarcane farmers, 13 farmers are operating at CRS (scale efficient), 83 farmers are operating at IRS and the rest (4) are operating at DRS. This implies that sugarcane farms can reduce cost production further by increasing their scale of operation to increase efficiency. 


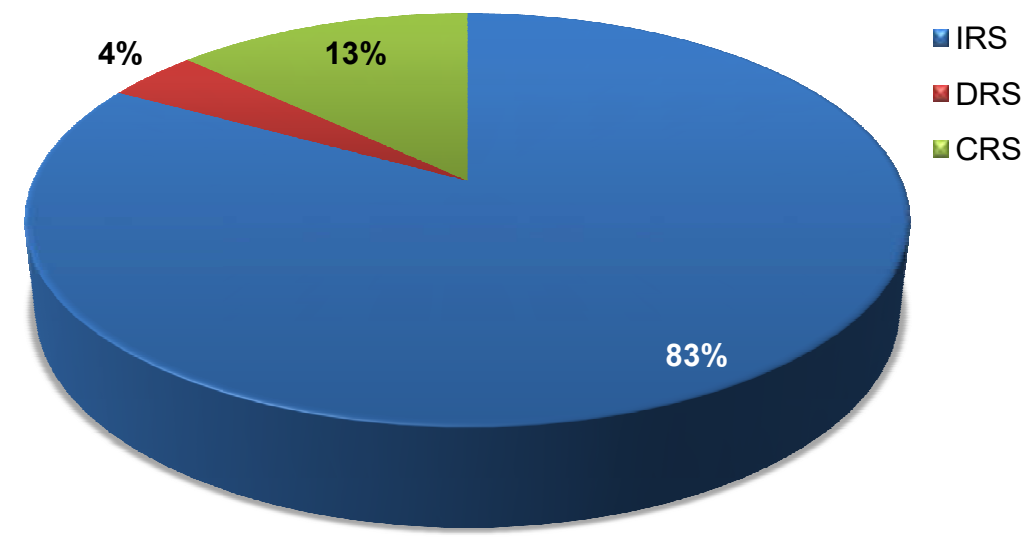

Figure 1 - Distribution of Farms based on Return to Scale

\section{CONCLUSION}

This study showed that there are resource-use inefficiencies in sugarcane production in Kediri District (64\% of sample). On average, pure technical efficiency level of sugarcane farmers is $91.7 \%$ therefore sugarcane farmers could increase their output by $8 \%$ through better use of available inputs by rationalizing the use of input production especially seed, fertilizer and herbicide.

Most of sugarcane farm are not operating in optimal scale (83\%). Majority of farms are operate Increasing Return to Scale (IRS) This suggest that sugarcane farms can reduce cost production further by increasing their scale of operation to increase efficiency.

\section{ACKNOWLEDGEMENTS}

Our profound and unreserved gratitude goes to Ministry of Research, Technology and Higher Education for financial assistance of this research.

\section{REFERENCES}

1. Coelli, T., S. Rahman, and C. Thirtle. (2002). Technical, Allocative, Cost and Scale Rice Production in Bangladesh: A Non-parametric Approach. Journal of Agricultural Economics, 53(3): 607-626.

2. Toharisman, A. and Triantarti. (2016). An Overview of Sugar Sector In Indonesia. Sugar Tech., 18(6): 636-641.

3. Farrell, M.J. (1957). The Measurement of Productive Efficiency. Journal of The Royal Statistical Society. 120(3):253-290.

4. Coelli, T.J. (1995). Recent Developments in Frontier Modelling and Efficiency Measurement. Australian Journal of Agricultural Economics. 39(3): 219-245.

5. Fare, R., S. Grosskopf and C.A.K. Lovell. (1994). Production Frontiers. Cambridge University Press., Cambridge.

6. Banker, R.D., A. Charnes, and W.W. Cooper. (1984). Some Models for Estimating Technical and Scale Inefficiencies in Data Envelopment Analysis. Management Science. 30(9):1078-1092.

7. Charnes, A., W.W. Cooper and E, Rhodes. (1978). Measuring the Efficiency of Decision Making Units. European Journal of Operational Research. 2: 429-444.

8. Fried, H., Lovell, K. and Schmidt, S. (2008). The Measurements of Productive Efficiency and Productivity Growth. Oxford University Press, New York. 